\title{
Manipulation as an ideological tool in the political genre of Parliamentary discourses
}

\author{
Ana Belén Cabrejas-Peñuelas \\ University of Valencia
}

The present study analyzes the discursive strategies of manipulation in the political genre of a discourse in Parliament with an aim to convince the audience that the Prime Minister and his party are innocent of receiving illegal cash donations from a slush fund run in the party. For that purpose, we have used Van Dijk's (2006) scheme of strategies of manipulation at several levels of discourse (content, lexis, topics, syntax, rhetoric, and order of discourse). Findings of the study show that the Prime Minister's speech presents characteristics of ideological discourse, since it follows a general strategy of positive in-group and negative outgroup presentation, which has an overall legitimating function. At other levels of discourse, the denial of controversial actions is made manipulative by following strategies of emphasis of our positive and their negative actions with the final aim of self-legitimating himself and his discourse. The discourse is further made manipulative by using appropriate contextual constraints and defensible semantics of representation.

Keywords: manipulation strategies, self-legitimation, ideological discourse, political speech

\section{Introduction}

Political discourse in general and political speeches in particular have been widely studied to find out what it is that politicians do to convince and appeal to the public. It seems clear that they systematically use the language to obtain political effects, such as making the audience believe or do things that are in the interests of politicians and against the best interests of the people (Blass 2005; Van Dijk 2003, 2006). One well-known example is governmental and/or media discourse, which is often used to blame immigration for the evils of a country's economy so that citizens do not blame the government policies (Van Dijk 2003). This type of discourse is termed manipulative and its communication proceeds like any other communicative exchange 
in the sense that addressees assume speaker cooperativeness (in the Gricean sense) and, thus, they attempt to retrieve the speaker's intention. However, there is really a "mismatch between speaker intention and the intention attributed to her by the addressee" (Maillat and Oswald 2007, 359), which results in the addressee's manipulation. Cognitive heuristics and the pragmatics of manipulation attempt to explain manipulative communication by explaining how the human mind processes information and how this is exploited to guide irrational beliefs and decisions.

One type of political discourse where politicians may be willing to use manipulation is Parliamentary discourse. It is formed of interventions (questions, answers, dialogs, whole discourses) before members of Parliament (MPs) that are used by politicians for the peaceful resolution of problems. They are often broadcast on radio and television and reported in the press. A well-known example is Blair's speech in the British Parliament to legitimize the war against Iraq in March 2003. Parliamentary discourse has characteristics that are typical of other formal genres, such as speaker and turn control by the Speaker of the House, length of turns, formal lexicon, complex syntax and the usual structures of argumentation and persuasion (Van Dijk 2005a, 8). And, yet, there are forms that are only found in Parliamentary discourse, such as forms of address ("Su Señoría" in the Spanish Parliament 'Your Honors'); indirect forms of address (the third person singular or plural pronoun ("usted/ustedes" 'you'); the MPs' first and last names; their current function ("diputados" 'MPs'); their honorary title (“don/doña” $\mathrm{Mr} / \mathrm{Mrs} / \mathrm{Ms}$ )); and the use of the first person plural pronoun "nosotros" 'we.' According to Van Dijk (2005a), what is typical of Parliamentary discourse is the combination of all of them and, thus, it can be regarded as a genre in itself. He further indicates:

What is exclusive of parliamentary debates as a genre, however, are such obvious context categories as the Setting (House of Parliament), the Participants (MPs, opposition, etc.), the Aims (policies, etc.), ${ }^{1}$ and the political knowledge and ideologies of the participants. In other words, although content and even style of what is said in parliament may be shared by other types of communicative events, the function of such structures should be established in relation to the specific political situation: The speakers-MPs are 'doing' politics, legislate, represent the voters, govern the country, and so on (italics in original).

(Van Dijk 2005a, 8-9)

In this study, we attempt to analyze the discursive strategies of manipulation employed in a Parliamentary speech made by the Spanish Prime Minister Mariano Rajoy when defending himself and the party he represents from accusations of a slush fund run by the Popular Party. The debate has been selected because the

1. Van Dijk (2005) relies on Dell Hymes's categories of setting, participants and aims. 
speech came about in a context of a serious economic crisis in Spain and a political crisis engulfing the Popular Party, which required Rajoy to convince politicians and citizens that the accusations of corruption in his party were false. We believe that the discursive strategies used are fundamentally ideological and, thus, are aimed at legitimizing the Government's domain and reproducing it. For the analysis, we have used Van Dijk's (2006) scheme of manipulative processes, Martin and White's (2005) theory of evaluative language and Lakoff and Johnson's (1980) conceptual metaphor theory so as to examine Rajoy's speech in Parliament on 1st August 2013. The following research questions will be analyzed:

Which types of manipulative process(es) found in Van Dijk's (2006) categorization of manipulation does Rajoy employ to convince the audience (the MPs) that he and the Popular Party are innocent of having received undeclared cash donations? How has Rajoy used the manipulative processes to legitimate his actions?

\section{The concept of manipulation}

Before embarking on making a theoretical and practical analysis of data, we must first define the term 'manipulation' in political argumentation as an illegitimate control used by the manipulator over other people to make them believe that things are done in their best interests when, in fact, they only favor the manipulator. Therefore, manipulation "not only involves power, but specifically abuse of power, that is, domination" (italics in original) (Van Dijk 2006, 360). It is "intentional" and "covert" (italics in original) (Van Eemeren 2005, xi), benefits the speaker's interest (Saussure 2005, 119) and implies an asymmetrical relation between the two parties involved (Saussure and Schultz 2005, 6). And, yet, the relationship between them is based on trust, which the manipulator often gains by engaging in argumentation (Blass 2005, 172).

In manipulative communication, two layers of intention can be distinguished: the informative intention and the communicative intention (Sperber and Wilson 1995). Thus, when the manipulator informs the audience of something (i.e. informative intention), s/he also communicates an intention (i.e. s/he expresses his/ her wish to inform the audience of the informative intention); however, this does not coincide with his/her covert manipulative intention. Therefore, it is left up to the listener to endeavor to recover the speaker's meaning and this may or may not always happen and indeed often does not. Hence, in manipulation we can say that "the manipulative intention is covert and not part of the communicative intention, in order to hide the deception" (Blass 2005, 177). This is in stark opposition to any of the recognized forms of legitimate manipulation, such as education and persuasion: 
[...] manipulation could be a form of (legitimate) persuasion [...]. The crucial difference in this case is that in persuasion the interlocutors are free to believe or act as they please, depending on whether or not they accept the arguments of the persuader, whereas in manipulation recipients are typically assigned a more passive role: they are victims of manipulation. This negative consequence of manipulative discourse typically occurs when the recipients are unable to understand the real intentions or to see the full consequences of the beliefs or actions advocated by the manipulator. This may be the case when the recipients lack the specific knowledge that might be used to resist manipulation $[\ldots]$.

(Van Dijk 2006, 361)

It seems, therefore, that for Van Dijk the difference between manipulation and persuasion lies less on the linguistic features of a given discourse than on the social and interactional structures in and by which the discourse acts. Indeed, "social conditions of manipulative control [...] need to be formulated - at least at the macro level of analysis - in terms of group membership, institutional position, profession, material and symbolic resources and other factors that define the power of groups and their members" $(2006,362)$.

The cognitive processes underlying the interpretation of manipulative discourse are the focus of attention of the Relevance theory (Allot 2013; Blass 2005; Sperber and Wilson 1995). According to this theoretical account, human cognitive processes are "geared to achieving the greatest possible cognitive effect for the smallest possible processing effort" (Sperber and Wilson 1995, vii). This implies that both the speaker and listener are moved to make a cognitive effort on the assumption that this will achieve the greatest positive cognitive effect on the listener or speaker, respectively. Since each utterance is "an open attempt to take up some of the hearer's precious attention" (Allott 2013, 79), the speaker is expected to be optimally relevant. However, in manipulation the manipulator only seems to be optimally relevant when in the act of achieving his/her own ends.

One might wonder how easy it is to manipulate an audience. For Sperber (2000), humans have a logico-rhetorical ability to check a message for internal and external consistency (i.e. contextual consistency), which is used "as a means to filter communicated information, and, [...] as a means to penetrate the filters of others" $(2000,14)$. However, manipulators can deceive them into believing manipulated information by "applying constraints $[\ldots]$ on the process of information treatment" (Saussure 2005,117 ) by using local and global strategies. Local strategies, whether linguistic or non-linguistic, serve to constrain the interpretation of information, whereas global strategies help to create the adequate social and psychological conditions for manipulation by resorting to group pressure and by building an over-competent image for the manipulator. High rates of some formal features are, thus, found in manipulative discourse; however, manipulative discourse is better 
described as "a type of usage of natural language" (italics in original), which is identified "only through notions like goals, intentions, and broader aspects of pragmatic processing" $(2005,118)$. Among the local linguistic strategies are rhetorical questions; misuse of concepts; religious discourse; and analogies, metaphors and vague terms. The non-linguistic strategies comprise prosodic features, intonation and eliciting emotional reactions (Saussure 2005, 127). For Saussure (2005, 129-130), the global strategies include recurrent use of specific connotative words; generalization of a new terminology; elimination of lexical items from public discourse; use of unmotivated or misleading analogies; use of acronyms, abbreviations and numbers; and naming of elements of the everyday environment. The final aim of all strategies is to "create a global atmosphere where depersonalization is progressively integrated and accepted as conventional and normal" $(2005,130)$.

After local and global strategies have been used, the listener may display three increasingly sophisticated strategies, which might correspond to different developmental stages: naïve optimism, cautious optimism, and sophisticated understanding (Sperber 1994). A naïve optimistic listener accepts the first relevant interpretation of information and equates it to the speaker's meaning, since s/he assumes that "the speaker is both competent and benevolent - competent enough to avoid misunderstanding and benevolent enough not to lead him astray" (Wilson 2000,421 ). A cautiously optimistic listener is able to deal with those cases in which the speaker has not been relevant and wonders what interpretation the speaker may have intended. In this case, the listener "assumes that the speaker is benevolent but not necessarily competent" $(2000,421)$. Finally, the sophisticated understanding strategy allows listeners to cope with those utterances that seem relevant, but are not, since "speakers are not always benevolent" $(2000,422)$. Such is the case of manipulation.

In this article we are interested in social domination of the manipulator over the manipulated and its reproduction in discourse. This type of domination implies "power abuse, [which] requires special access to, or control over, scarce social resources" (Van Dijk 2006, 362). Some of such social resources are, according to Van Dijk (2006, 362), the mass media or public discourse, which can only be approached by elite members of society (politicians, writers, scholars, journalists) by using different discourse forms: news, newspaper articles, electoral debates, Parliamentary debates and others. ${ }^{2}$ Van Dijk expressed it as follows:

2. In his 2006 publication, van Dijk seem not to be particularly aware of the changing media ecologies brought about by social media and the changes in news consumption patterns more broadly. 
Power may be defined in terms of control. Normally, this means the power of action: A can control (limit, prohibit) B's actions. Since discourse is a type of action, such control can also be exercised over discourse and its properties: the context, topic and style. And, given that discourse influences the receptors' minds, powerful groups can also indirectly control (e.g., through the media) other people's minds. We are therefore talking about persuasion or manipulation (our translation).

(Van Dijk 2003, 47)

No doubt, the 'victims' of such elite members are everyday people who may not understand the elite members' manipulative moves. But, even more informed 'victims' such as parliamentary members may be manipulated, as they often lack relevant information that may be in the hands of a few or take decisions 'forced' by wider political consequences.

Following Van Dijk (1998, 2001), this article has an overall multidisciplinary framework, which triangulates a social, cognitive and discursive approach. Manipulation is therefore considered a social phenomenon, since it involves social relations of power abuse between groups or individuals. It is also a cognitive phenomenon, because manipulation involves the participants' minds. Finally, it is a discursive phenomenon, because it is exercised through text, talk and visual images (Van Dijk 2006, 361).

\section{Social-political manipulation as an ideological tool}

Political manipulation of Parliamentary members has been studied in the discourses that followed the September 11 and March 11 terrorist attacks in New York and Madrid (Graham et al. 2004; Leudar et al. 2004) and in Tony Blair's and George Bush's discourse to legitimize their government's decision to go to war and invade Iraq (Oddo 2011; Van Dijk 2006). In such discourses as well as in the discourse of racism or antiracism (Van Dijk 2000, 2003) lexico-semantic resources are often deployed that serve to legitimate our actions and contribute to the ideological polarization that justifies violence that seems necessary. The concept of 'ideology' is defined as follows:

Ideologies are the foundation of the social beliefs shared by a social group. In other words, a bit like the axioms of a formal system, ideologies consist of those general and abstract beliefs, shared by a group, that control or organize the more specific knowledge and opinions (attitudes) of a group.

(Van Dijk 1998, 49)

For Van Dijk (1998, 183), elite ideologies may be successful with dominated groups even when their actions are not always in the best interests of their members. This may be explained by the fact that dominant groups often control the means of 
ideological reproduction, which is especially the case of the mass media, and display various mechanisms of manipulation. These consist in "ton[ing] down the obviously inconsistent parts of the ideology and emphasiz[ing] those parts that may be more attractive" $(1998,183)$, even when they may have multiple negative consequences for the dominated groups, which are, therefore, obscured or eliminated.

Ideological discourse that is markedly manipulative presents attributes that serve the purpose of transmitting the ideology of those in power. Such attributes are also "attributes of political discourse (especially parliamentary)" (2003, 96) (our translation), such as "Us vs. Them" polarization, positive characteristics of "Us", negative characteristics of "Them" and nationalist feelings. All these categories for social-political manipulation may affect the meaning of the text, but they may also affect the morphology (word formation), lexis and syntax (sentence formation). However, it is more likely for content to be affected, since "ideological 'content' is expressed more directly through discourse meaning” $(2003,58)$ (our translation). Van Dijk $(2006,373)$ indicates the following discursive strategies of manipulation (DSM):

1. Positive self-presentation vs. negative other-presentation, which is nothing but a biased presentation of facts in one's own favor, while blaming the opponents (typically, immigrants, the young, terrorists and others). There is, therefore, a categorical division of people as members of a group (We) and non-members (They). Ideological positive self-presentation and negative other-presentation also imply the following $(2003,58)$; they:

- Emphasized "Our" positive aspects.

- Emphasized "Their" negative aspects.

- Deemphasized "Our” negative aspects.

- Deemphasized "Their" positive aspects.

2. Macro-speech acts imply "Our "good' acts and "Their" 'bad' acts, e.g., accusation, defense.

3. Semantic macro-structures: topic selection, which is directly related to (de-) emphasizing "Our" positive and "Their" negative aspects.

4. Local speech acts implementing or sustaining the global ones: statements that prove accusations.

5. Local meanings related to "Our/Their" positive/negative actions: We are generally more specific (give more details, are more explicit, are more precise, and so on) about our positive points than our negative ones and vice versa.

6. Lexicon: positive words for us and negative words for them.

7. Local syntax: the use of active or passive sentences and nominalizations is related to an interest in (de-)emphasizing "Our/Their" positive/negative agency.

8. Rhetorical figures: hyperboles, euphemisms, metonymies and metaphors. 
9. Use of sound and visuals (order; emphasis by using loud sounds or large and bold letters): Information is emphasized by placing it at the beginning of a text, since "information expressed at the head of a sentence has most emphasis as it is heard and understood first and as a result better influences the interpretation of the rest of the text" $(2003,70)$ (our translation). Similarly, it can be de-emphasized by placing it at the end.

In order to consider whether words contribute to the overall positive/negative presentation, we use the Appraisal theory, which serves to describe how language is used to evaluate and how attitudes, judgments and affects are expressed in text. The Appraisal Theory distinguishes between Graduation (evaluation related to intensification), Engagement (evaluation related to the use of different voices) and Attitude (evaluation that deals with "our feelings, including emotional reactions, judgements of behaviour and evaluation of things" Martin \& White 2005, 35). In this study, we concentrate on Attitude for examining ideological positive/negative presentation, which includes the following subtypes:

Attitude $\left\{\begin{array}{l}\begin{array}{l}\text { Affect } \\ \text { (emotional reactions }) \\ \text { Judgment } \\ \text { (evaluation of human behavior })\end{array} \\ \begin{array}{l}\text { Happiness/unhappiness } \\ \text { Security/insecurity } \\ \text { Satisfaction/dissatisfaction }\end{array} \\ \begin{array}{l}\text { Appreciation } \\ \text { (evaluation of reality and humans })\end{array} \\ \begin{array}{l}\text { Social sanction: moral regulations \& ethics } \\ \text { live up to expectations }\end{array} \\ \begin{array}{l}\text { Reaction: whether we like it or not } \\ \text { Composition: how the text goes together } \\ \text { Valuation: evaluation of the text content }\end{array}\end{array}\right.$

For the analysis of metaphors (DSM 8), we have used Lakoff and Johnson's (1980) conceptual metaphor theory, which states that two concepts (A and B) are in a metaphorical process when $\mathrm{A}$ is understood in terms of $\mathrm{B}$ and, thus, "there is a set of correspondences between the source and the target in the sense that constituent conceptual elements of B correspond to constituent conceptual elements of A" (Kövecses 2010, 7). Example: "erosion that some cultivate" (conceptual metaphor: HARM IS/ARE A PLANT/CROPS, source domain: a plant/crops, target domain: harm).

One might argue that not all social-political discourse is necessarily manipulative, but it may be persuasive, which makes it necessary to analyze what "contextual constraints prevail, namely on participants, their roles, their relations and their typical actions and cognitions (knowledge, goals)" (Van Dijk 2006, 372). These typically indicate whether the discourse is manipulative or persuasive. It is however true that, as stated earlier, for manipulation to exist the specific constraints refer to the manipulator's dominant position over the manipulated; the lack of relevant 
knowledge of the manipulated, which the manipulator is aware of; and the result of manipulation being to the manipulator's own benefit.

Next, we are going to present the political context that lies behind Mariano Rajoy's speech in the Spanish Parliament made to explain the Bárcenas affair.

\section{Mariano Rajoy's speech in Parliament (1st August 2013): The political context}

The political context preceding the speech in Parliament of the Prime Minister, Mariano Rajoy, was one of economic crisis, high unemployment rates, biting austerity cuts to basic services and corruption scandals affecting several political parties and the royal household, which brought increased scrutiny to political parties and the monarchy. Public disaffection with the economic crisis gave rise to the so-called "Citizens' wave," bringing together various protest movements (health services, education, social services) and the "indignados" ("the outraged") movement (formed by young and old Spaniards alike camping out in Madrid's main square in 2011 in objection to the modus operandi of the political system and which was linked to the "Occupation" movement in other parts of the world)). Such protest movements took over squares around Spain in protest over privatization, austerity and eviction, which was leaving families homeless, and forcing the government to debate a change of the current mortgage law that left families without a house and yet still carrying mortgage debt for life. Mass demonstrations around the country further protested after revelations of apparent corruption cases in the Partido Popular party (henceforth, PP) for several months, which led to a round of instability of the Euro zone crisis. Indeed, a presumed network of political corruption related to the PP camp - the Gürtel ${ }^{3}$ case - was uncovered by the newspaper El País in 2009. ${ }^{4}$ The leader of the group Francisco Correa and three of his right-hand men Álvaro Pérez, Pablo Crespo and Antoine Sánchez-were accused of paying millions of Euros in kickbacks in exchange for public contracts from the PP administration in Madrid, Valencia and Castilla-la-Mancha. The corruption network grew even more in the following years due to their friendship with PP politicians and former President Aznar's family, until Correa and his network were finally investigated by National Court judge Baltasar Garzón. Correa, his corruption network, as well as

3. German translation of "Correa", which is the last name of the corruption network leader.

4. The newspaper El País published the article "Perfil de la corrupción: Corrupción a la sombra del poder" [Corruption profile: Corruption to the shadow of power] about "the Gürtel case", which revealed the largest corruption scandal in recent Spanish history <http://elpais.com/diario/2010/04/18/domingo/1271562756_850215.html>. 
some politicians belonging to the PP were accused of bribery, money laundering and tax evasion for their alleged illegal activities. The corruption case was handed over to judge Ruz when Garzón was himself accused of and found guilty of making illegal recordings of conversations between lawyers and their clients. Judge Ruz implicated PP politicians in Alicante and the Balearic Islands and reopened the Gürtel case against the PP ex-treasurer, Luis Bárcenas, for illegal public contracts.

In 2013 the Gürtel case became even more complicated when a further corruption case evolved within the PP party in relation to the Bárcenas affair. The scandal broke out following the publication of extracts from the former treasurer and Senator Luis Bárcenas's handwritten accounts. ${ }^{5}$ These indicated that some senior members of the PP party had been receiving undeclared cash donations for two decades that came from private building construction companies and other businesses and, thus, the PP camp had a double accounting system. The newspaper $E l$ País stated that among those included in the handwritten accounts were the current Prime Minister, Mariano Rajoy, and other former ministers (Cué et al. 2013), while the opposing leader Alfredo Pérez-Rubalcaba called on Mariano Rajoy to resign over the accusations. Bárcenas denied having written the accounts and, yet, he was sent to prison in June 2013 on charges of tax fraud and money-laundering when the judge perceived that there was risk of the ex-treasurer leaving the country. When the accused felt that the PP party was not supporting him, he admitted the accusations in an interview to the conservative newspaper El Mundo and added that the documents published by El País were only a small fraction of those he possessed. ${ }^{6}$ For Popular politicians, Barcenas's claims were false and they affirmed that there was only one set of accounts, and this was transparent and legal. ${ }^{7}$ For Spaniards, what the corruption cases really called into question was the then current system, which seemed rather opaque and easy to manipulate and allowed money to be given and contracts to be signed under the table by the upper political classes. On 1st August 2013, Mariano Rajoy addressed the Spanish Parliament upon the threat of a motion of censure issued by the opposing party, which demanded he explain Bárcenas's accusations of illegal payments from a slush fund in the PP party.

5. The handwritten accounts have been widely known as "Bárcenas's papers" (los papeles de Bárcenas).

6. The newspaper El Mundo describes the undeclared and untaxed donations received by the $\mathrm{PP}$ politicians for years and the ex-treasurer Bárcenas's threats to the PP camp if they did not help him out to avoid prison. See <http://www.elmundo.es/elmundo/2013/01/18/espana/1358536985. html>.

7. The newspaper El País published on May 15th, 2014 that Judge Ruz considered proved that the PP party had been financed illegally and PP officials had received untaxed extra payments. See <http://politica.elpais.com/politica/2014/05/14/actualidad/1400099131_887893.html>. 


\section{Methodology}

For the study of manipulation, Rajoy's parliamentary debate (7,582 words) was taken from the Government's official webpage. ${ }^{8}$ The transcript was copied and pasted in text format to be uploaded to a freeware program called UAM corpus tool, developed by Mick O'Donnell. ${ }^{9}$ This software is, in fact, a set of tools to annotate the text(s), make searches in the corpus and run descriptive and inferential statistics. For the analysis of manipulative processes, we inserted Van Dijk's $(2006,373)$ levels of analysis for social-political manipulation explained in Section 3 of the article. To achieve inter-rater reliability, the researcher analyzed the whole debate and then another researcher, who was also well acquainted with political discourse, analyzed $30 \%$ of the text. Both analyses had $81.58 \%$ agreement for levels of analysis. A third rater was asked to analyze it, since the rate obtained seemed rather low. This time we reached $87.65 \%$ agreement. Those cases in which there was no agreement were discussed until a consensus was reached.

Before the analysis, some terms needed clarification. The distinction between sentence and utterance was of great importance, since they did not always coincide. A sentence is a grammatical entity derived from the language system, whereas an utterance is an "instance of such entity, identified by [its] use in a particular situation" (Leech 1995, 14). But a sentence does not always coincide with an utterance. An utterance corresponds to a micro-speech act, which may include one or more speech acts, and be of several types such as greetings, claims, requests.

For the study, we carried out a content analysis, assigning labels corresponding to the discursive strategies of manipulation (DSM). In most cases, labels were assigned to individual sentences (from capital letter to full stop) for DSM 5, 7, 8 and 9. However, sentences were analyzed in context (i.e. the sentences occurring immediately before and after the sentence being considered) to understand their full meaning. See Example (1): ${ }^{10}$

(1) I say so with all frankness: I lacked any reasons to doubt his innocence. So, I trusted him and supported him. Yes, I supported him, as I would support anyone that went through a persecution that I thought unfair. I believed in his innocence [interaction strategies: negative other-presentation].

8. The transcript and video of Mariano Rajoy's intervention in the Spanish Parliament can be found on the Moncloa webpage. <http://www.lamoncloa.gob.es/Presidente/Actividades/ ActividadesNacionales/2013/1813Congreso.htm $>$.

9. The program can be downloaded for free from the web page: http://www.wagsoft.com/ CorpusTool/.

10. All extracts taken from Rajoy's speech have been translated into English due to space restrictions. 
In (1), the first sentence was analyzed as contributing to our positive self-presentation, since the Prime Minister shows himself as not doubting of his friends, until evidence shows that the contrary is true. The second and subsequent sentences serve to show him as a supporter of his friend and of those going through difficulties unfairly. The speech act was considered the unit of analysis for DSM 1, 3 and 4; the word or phrase, for DSM 6; and the discourse, for DSM 2. Also, micro-speech acts were often formed of two or more speech-acts, such as the remembrance formula used at the beginning of the speech. Thus, given the increasing difficulty for the researchers to analyze the data and reach an agreement, we decided to pre-assign the units of analysis. The results indicate that there were a total of 313 sentences, 1 macro-speech act, 780 words and phrases and 146 micro-speech acts. The quantitative examination was then followed by a qualitative one that gives account of the textual/discursive level of the discourse. Extracts taken from the Prime Minister's discourse in Parliament were analyzed at the syntactic, lexical and semantic and discourse levels, using Van Dijk's (2006) manipulative categories, and analyzing their discursive logic and interdependence to ideologically mark the text. The extracts selected are a number of characteristic fragments of Rajoy's speech; however, as in Van Dijk (2005b), we have not employed any procedures for the selection of the fragments, other than those typical of political discourse and, particularly, theories of parliamentary debates.

The second methodological decision was related to the need to distinguish the textual features that were regarded as expressing Van Dijk's (2006) strategies. For DSM 1 and 6, we analyzed the polarity of words - positive, negative or neutral following Martin and White's (2005) Appraisal Theory, which explores the language of evaluation. Indeed, Van Dijk $(2005,68)$ considered evaluation to be a "global semantic strategy of positive presentation of $U s$ and negative other-presentation of Them" that is typical of political discourse and political language. In the study, the words were examined in each sentence and in context (i.e. the words occurring immediately before or after the word or phrase under consideration) before deciding whether they had positive, negative or neutral evaluative meanings and, thus, contributed to the overall positive/negative presentation. For example, see Example (2), in which "believed" and "supported" have positive evaluative meanings (DSM 6):

(2) I believed in him and supported him [appraisal: attitude: judgement: property: positive]

The semantic macrostructure of Rajoy's speech (i.e. global meaning that organizes the local meanings of words at the higher levels of paragraphs and discourse (Van Dijk 2012)) corresponds to the topic of the discourse (DSM 3): the Prime Minister and the party he represented were innocent of the accusations of illicit payments from a slush fund, as stated in Bárcenas's ledgers. It is however true that, for Van Dijk (2012), 
topics, like semantic macrostructures, control local meanings and, thus, positive topics about "Us" organize positive local meanings and negative topics about "Them" organize negative local meanings. These may range "from words to complex descriptions of situations, events, actions, and people" (Van Dijk 2012, 25). To find out about the semantic macrostructure of the speech, utterances were analyzed as "emphasized negative/positive topics" or "de-emphasized negative/positive topics," whichever being the case at the time, depending on their local meanings. See Example (3).

(3) What can I tell them, Your Honors? What's the use of telling them anything? [semantic macro-structure: emphasized negative topics].

Van Dijk $(1992,215)$ also distinguished between macro-speech acts and micro-speech acts or local speech acts, which take 'speech act' as the unit of analysis. In this study, the boundary of a speech act is the clause (also, Şimon 2008, 54), since speech acts can be combined in higher-level speech act sequences; that is, sequences of two or more speech acts that depend on each other. Macro-speech acts are defined as "the global speech act performed by the utterance of a whole discourse, and executed by a sequence of possibly different speech acts" (Van Dijk 1992, 232). Micro-speech acts refer, however, to the structure of individual speech acts and the linear structure of speech act sequences. This suggests that the speech acts of a discourse are organized linearly in sequences and hierarchically in global speech acts, which serves to give an account of the pragmatic structure of a discourse (1992, 232). Regarding the macro-speech act (DMS 2), Rajoy's speech functions as an act of information (illocutionary act), as it was primarily intended to inform about the Bárcenas affair. The perlocutionary act was an act of persuasion (i.e. convincing the audience that the Prime Minister and the Popular Party were innocent of the accusations of illegal payments). However, drawing a distinction between micro-speech acts, which were composed of one or more speech acts, was a difficult task, since it involved distinguishing between different types of speech acts. In the speech, these micro-speech acts were identified: a remembrance, a thanks formula, assertions, claims, requests, questions, directions, suggestions, accusations, and promises (DMS 4). These follow Brinker's (1997, 105-121) textual categories (i.e., information, appeal, obligation, contact, and declaration), ${ }^{11}$ which take into account an interpersonal relation between at least two participants in the speech communication:

11. The content of Brinker's text types overlaps with Searle's (1969) types. Informatives overlap assertives, appellatives with directives, obligatives with comissives, contactives with expressives and declaratives with Searle's declaratives. 
a. A text has an informative function if the addresser uses it to convey information to the addressee. An informative text may be descriptive, argumentative or narrative.

b. We speak of a text having an appellative function if the addresser asks the addressee to act in a certain way. Appeals take the form of a question or a direction to do something.

c. A text has an obligation function if the addresser commits himself to acting in a certain way. Obligations take the form of offers and promises.

d. Texts with a contact function are intended by addressers to get into contact with and establish a social relationship with addressees.

e. Declarations serve the purpose of bringing about a change of the state-of-affairs that coincides with the propositional content of the text.

In the present article, the last textual category, declarations, is of no interest, since politicians' speeches in Parliament do not have a declarative function. See Example (4).

(4) Let's talk clearly, Mr. Pérez Rubalcaba [micro-speech act: appeal: suggestion]. Your Honor has considered presenting a Motion of Censure as a threat to make appear in Parliament [micro-speech act: appeal: accusation]. Don't threaten me, Mr. Pérez Rubalcaba, with a Motion of Censure. As I said at the outset and I repeat again now, one doesn't threaten using the Constitutional instruments [micro-speech act: appeal: direction].

The final methodological decision referred to the use of a statistical hypothesis test: the one- or two-tailed tests. According to the statistician's advice (personal communication), hypothesis tests were selected because they serve to check whether or not there are differences between the items, as the rates indicate. In the one-tailed test we hypothesize that there are differences between two groups (e.g. positive self-presentation vs. negative other-presentation) and we specify in which direction the differences exist (e.g. more positive than negative presentation). In the two-tailed test, we also predict a difference between two groups; however, we make no reference to the direction of the differences. In those cases in which multiple comparisons could be made, we only concentrate on those rates that are closer to each other so as to verify that there are really differences between them.

For the identification of metaphors, we compared the contextual and basic meanings of the lexical units being examined and decided whether or not the two of them differed (Johnson and Lakoff 1980). If that was the case, the units were marked as metaphorical. Ex: "the erosion to Spain's image that some cultivate" (contextual meaning of "erosion": image that is gradually damaged, basic meaning: damage to the soil; metaphor: HARM IS A PLANT). Finally, for the analysis of Attitude, we 
carried out a content analysis of the speech, assigning labels corresponding to the Appraisal schemes, since we were interested in finding out the way Rajoy used language for ideological positive/negative presentation.

\section{Results}

This section deals with the manipulative strategies used by Mariano Rajoy in his speech in Parliament. We first present and discuss the results for manipulation in his speech ${ }^{12}$ in Parliament and, then, explore how he has used them to legitimate his actions before the audience.

The results of the study reveal that Rajoy's speech in Parliament on August 1st, 2013 has characteristics of ideological discourse, since it is organized by a general strategy of positive self-presentation and negative other-presentation that serves him to legitimate his actions and follows the in-group - out-group polarization. Indeed, close examination shows that a large proportion of utterances in the speech are intended to offer a positive presentation of the speaker and the group Rajoy represents $(30.14 \%)$, while there is also a negative presentation of the opposing party $(32.19 \%)$ in such a way that it legitimates not believing them $\left(\mathrm{T}=0.378, \mathrm{z}_{\alpha}=1.96\right.$, $p<.05$; since $0.378 \in[-1.96,1.96]$, then $\mathrm{H}_{0}: \mathrm{p}_{\text {pos }}=\mathrm{p}_{\text {neg }}$ is rejected, which confirms the result that the rate of utterances for positive self-presentation and negative other-presentation is very similar) ${ }^{13}$ (see Table 1 ). Similarly, the rate of words or phrases that are positive about "Us" (i.e., positively evaluated) is very similar to the rate of words or phrases that are negative about "Them" (i.e. negatively evaluated): 50.90\% versus $49.10 \%$, respectively $\left(\mathrm{T}=0.5296, \mathrm{z}_{\alpha / 2}=1.96\right.$; since $0.5296 \in[-1.96,1.96]$, we can conclude that, as expected, the percentage of positive and negative lexicon is the same or very similar) (see Table 2). Terms referring to the speaker and his group are, therefore, positive, as are their acts ('our good acts'): the use of a captatio benevolantie at the beginning of his speech and his closing are part of his overall strategy of positive self-presentation. In the captatio benevolantie, Rajoy remembers those who died in the train accident in Santiago, the rescue members and all those neighbors who helped with the victims, whereas in his closing he shows a disposition to always supporting Spain.

Right after the captatio benevolantie, Rajoy engages in various forms of positive self-presentation, especially given the devastating critique that the accusations of

12. Due to space restrictions, we only provide the overall percentages of some of the manipulative processes found in Rajoy's speech.

13. In this study, we take $p<0.05$; that is, a significance level of $95 \%$, which is considered significant in social sciences (Dörnyei, 2007, 210). 
illegal cash payments to PP politicians and his refusal to discuss the allegations received in the media, from other political parties and from the majority of Spaniards. See Example (5), in which the Prime Minister addresses the criticism that he ignores pressure to discuss allegations of corruption.

(5) I have requested appearing in this House to offer Spaniards through their legitimate representatives the clarifications and explanations that I think are necessary due to the situation we are experiencing. [...] It is not the first time I have spoken about this issue. I already did so in an open hearing for the benefit of all Spaniards at the beginning of February and some weeks later we debated about this topic in this House during the Debate about the State of the Nation. On numerous occasions and in diverse scenarios I have been questioned about the same thing.

Table 1. Raw numbers and percentages of interaction strategies and macro-speech acts

\begin{tabular}{|c|c|c|}
\hline & Percent & $\mathrm{N}$ \\
\hline INTERACTION_STRATEGIES-TYPE & \multicolumn{2}{|c|}{$N=146$} \\
\hline Positive self-presentation & $30.14 \%$ & 44 \\
\hline Negative other-presentation & $32.19 \%$ & 47 \\
\hline Null & $37.67 \%$ & 55 \\
\hline TOTAL & $100 \%$ & \\
\hline MACRO-SPEECH ACT & \multicolumn{2}{|c|}{$N=1$} \\
\hline our-good-acts and their-bad-acts & $100 \%$ & \\
\hline
\end{tabular}

Table 2. Lexicon

\begin{tabular}{|c|c|c|}
\hline Feature & Percent & $\mathrm{N}$ \\
\hline LEXICON & \multicolumn{2}{|c|}{$N=780$} \\
\hline Positive self-presentation & $50.90 \%$ & 397 \\
\hline Negative other-presentation & $49.10 \%$ & 383 \\
\hline
\end{tabular}

Rajoy's detailed account of his explanations to MPs and to Spaniards about the ex-treasurer's accusations serves him the purpose of demonstrating that he offers the necessary clarifications and, thus, he is a good democrat. The evidence offered about his public appearances is important "to add objectivity, reliability and credibility" (our translation) (Van Dijk 2003, 108) and "contributes to the rhetoric of truth" (Martin Rojo and Van Dijk 1997, 536), since all these actions can be easily verified. The positive lexicon and the syntax used further enhance him as a democratic leader, who complies with the law: "I have requested appearing in this House" [appraisal: appreciation: positive; unmarked word order: positive agency], 
"clarifications and explanations that I think are necessary" [appraisal: appreciation: positive; unmarked word order: positive agency], "open hearing" [appraisal: appreciation: positive]. The lexicon is also specific and detailed: "some weeks later we debated this topic," "on numerous occasions and in diverse scenarios."

It is also imperative for the Prime Minister to provide evidence that explains his unwillingness to appear in Congress to explain the Bárcenas affair: he accuses the current opposition of creating an atmosphere of suspicion that is damaging the country's external reputation (see Example 6).

(6) Bringing sterile and unfounded debates to Parliament, riddled with unconfirmed suspicions and partial information can hardly be considered a gesture of respect to the House. That is why I haven't appeared until today. I didn't think what could be debated here would compensate for the bad effect this debate could have on our external reputation; but we have been pushed to the limit, Your Honors, in which the harm that has been already been caused to the country's image and to citizens' trust has started to become relatively small in comparison to the harm that may be done if Spain does not get into step and provides an answer to what is happening here.

Implicitly, he aligns himself with those who respect the law and associates the "Others" - i.e. the opposition parties (which is especially the case of the leftish party) and Bárcenas - with illegality. It is a strategy of legitimization of his policies and illegitimization of the "Others". The positive terms - "respect," "external reputation" [appraisal: attitude: appreciation: social valuation: positive], "that's why I haven't appeared until today" [appraisal: attitude: judgment: property: positive] - contribute to emphasizing the legality and correct procedures of the Government's actions for Spain's economic well-being at a moment of great economic distress, while the opposing party is damaging Spain's external credibility with the Bárcenas affair. However, the negative terms attributed to the Others are negatively evaluated "sterile and unfounded debates," "unconfirmed suspicions," "partial information" and "bad effect" [appraisal: attitude: appreciation: social valuation: negative] - and add to the idea that the "Others" are a threat to "Us". By linking "Them" to partiality, political interests and harm to Spain's image, their authority is undermined. Similarly, metaphors - THE DEBATE IS A CONTAINER (plagados de sospechas sin confirmar "riddled with unconfirmed suspicions"), SPAIN IS A HURT HUMAN BEING ("the harm that has already been caused to the country's image and to citizens' trust"), and GOVERNING Is A JOURNEY (hemos llegado a un extremo "we have been pushed to the limit," si no se sale al paso "if Spain doesn't get into step") - serve Rajoy the purpose of pursuing his rhetorical goals of persuasion and, ultimately, of legitimization and justification of his decision not to have appeared in Parliament previously. No doubt, metaphors "allow complex notions and phenomena to materialize 
in images" (our translation) (Martin Rojo 2000, 135) that are easily understood and, thus, contribute to persuasion.

Syntax also plays the role of ideologically marking the discourse: nominalization, marked word order, and passivization (verbs with se in Spanish, which are more common than the passive voice) ([...] puede difícilmente considerarse [...] "bringing sterile and unfounded debates to Parliament [...] can hardly be considered [...]"). These serve to emphasize "Their" negative agency by focusing the addressee's attention on the subject of the sentence. In contrast, in those sentences emphasizing "Our" positive agency Rajoy uses the active voice and unmarked word order: "That's why I haven't appeared until today," "I didn't think [...]." What is important here is that the Prime Minister does not mention the reasons behind the Socialist party's decision to issue a motion of censure. By only referring to the harm that the motion of censure does to Spain's external credibility, Rajoy dismisses their reasons and, hence, they are associated with self-interest.

The strategy of positive self-presentation further includes de-topicalizing the information that is inconsistent with Rajoy's interests, while at the same time topicalizing the information that stresses the negative properties of the opposing party. See Example (7).

(7) This is a story that started over four years ago, at the beginning of 2009, when, one fine day, we learnt that the Popular Party's treasurer had been charged with the so-called 'Gürtel case'.

In this extract, Rajoy de-emphasizes a sensitive issue for his party - the fact that the ex-treasurer had been legally charged - and he does so by using the schematic structure of a story ('This is a story that ...') and by leaving the most important information to the end of the sentence. This way, prominent information is downgraded to achieve the effect of distancing from the facts reported and, thus, the word order selected has an ideological function. However, in Extract (8) the Prime Minister topicalizes the information that is negative about the opposition's leader, Mr. Pérez-Rubalcaba, by using rhetorical questions in anaphoric position aiming at putting him in a negative light.

(8) You know that we need external financing at a reasonable price. We need it for everything. If you know this, as you do, why are you sowing doubts both inside and outside Spain? Why are you feeding the suspicions of instability? Why are you sabotaging the trust that Spaniards have gained in the markets? What great achievement do you expect to attain in exchange for our return to ruin?

[appraisal: attitude: judgment: property: negative]

Indeed, the rhetorical questions used serve to highlight a convergent thought: the opposition's leader acts with dishonesty and moved by self-interest. Also, the 
description is hyperbolic through the use of negative terms (see underlining) and the use of the DOUBTS ARE CROPS metaphor (sembrar dudas 'sow doubts').

The semantic macro-propositions of the speech also serve the Prime Minister to emphasize both positive topics about "Us" (e.g., improving the Spanish economic situation, including several measures to tackle corruption, denying any wrongdoing, acknowledging a mistake when trusting his ex-treasurer) and negative topics about "Them" (e.g., contributing to the erosion of Spain's image, telling lies and manipulations, taking advantage of the situation to obtain a benefit). However, examination of the semantic macro-structure of Rajoy's overall debate reveals that the rate of positive topics is higher $(56.85 \%)$ than that for negative topics $(34.25 \%)\left(\mathrm{T}=3.981, \mathrm{z}_{\alpha / 2}=1.645, p<.05\right.$; since $3.981 \geq 1.645$, then $\left.\mathrm{H}_{0}: \mathrm{p}_{\text {pos }} \geq \mathrm{p}_{\text {neg }}\right)$ (see Table 3), since Rajoy's speech in Parliament was mainly to disentangle himself from the tentacles of a funding scandal in his political party by admitting he had made a mistake when trusting a former disgraced colleague.

Table 3. Raw numbers and frequencies of semantic macro-structures for topic selection

\begin{tabular}{lcc}
\hline Feature & Percent & N \\
\hline SEMANTIC MACRO-STRUCTURE: TOPIC & & $N=146$ \\
\hline emphasized-negative-topics & $34.25 \%$ & 50 \\
emphasized-positive-topics & $56.85 \%$ & 83 \\
deemphasized-negative-topics & $2.74 \%$ & 4 \\
deemphasized-positive-topics & $0 \%$ & 0 \\
null & $6.16 \%$ & 9 \\
\hline
\end{tabular}

See Example 9, in which harm to Spain's image brought by the "Others" is a prominent topic in the Prime Minister's debate, which is also shown in the description level (specific and precise about "Our" positive intentions and "Their" negative ones) and in the syntax of the sentence.

(9) This is why I am here, Your Honors, to bring a halt to this erosion to Spain's image that some cultivate; to ensure that the harm to Spaniards, their interests and their future which keeps growing in a way that is, to my mind, irresponsible; and also to rebuff the lies, manipulations and malicious insinuations cheered on with enthusiasm by certain political leaders.

Certainly, the use of cataphoric 'this' ("This is why I am here [...]"), which serves to focus the addressee's attention on the object of the sentence; hyperbolic metaphors (HARM IS A PLANT and THE OPPOSITION IS A DESTRUCTIVE NATURAL FORCE: "erosion that some cultivate," "the harm [...] keeps growing" and "bring a halt to this erosion to Spain's image") and parallel syntactical structures ("to bring [...]; to avoid [...]; and to rebuff [...]")) add to "Our" positive and "Their" negative presentation 
("Our" good acts and "Their" bad acts). Example (10) shows another major topic in Rajoy’s debate: denying any illegal behavior and accusing the ex-treasurer of lying.

(10) Your Honors, I can't tell you anything else except that his accusations are false, his half-truths are false and the interpretations of the half a dozen truths that he employs as coverage for his falsities are false. The judge will determine what is appropriate about each one of the insinuations, but I can tell you in advance that in the Popular Party there has neither been a double accountancy system nor has an offence been hidden. Have salaries been paid? Yes. Have complementary payments been made for the position occupied? Yes. Have advance payments or prepaid expenses been made to be justified as expenses for the positions occupied? That too, like everywhere. It is fair. A job has been paid for, it has been paid legally and the payment has been included in the accounts.

In (10), the semantics are biased to positively evaluate "Us" and "Our" actions and negatively evaluate "Them" and "Their" actions: "It is fair. A job has been paid for, it has been paid for legally" [appraisal: attitude: judgment: property: positive] versus "his accusations are false, his half-truths are false [...]" [appraisal: attitude: judgment: property: negative]. Also, "Our" good acts are explained in detail (see Example (9)) and "Our" controversial acts - the fact that PP politicians get extra payments for their work - are explained in euphemistic terms. Therefore, this mitigation "is explained in ideological terms (protection of the in-group)" (our translation) (Van Dijk 2003, 108). Syntax and vocabulary also contribute to enhancing "Our" positive and "Their" negative actions through the use of anaphora and rhetorical questions. See the following examples:

a. "son falsas [...], son falsas [...] y son falsas [...]"

[his accusations are false, $[\ldots]$ are false, $[\ldots]$ are false]

b. "ni ...ni"

[neither ... nor]

c. “Se han pagado [...]? Sí ¿Se han pagado [...]? Sí ¿Se han pagado [...]? También" [have (subject) been paid [...]] Yes (impersonal rhetorical questions)

d. "Se ha pagado [...], se ha pagado [...]"

[a job has been paid for, it has been paid legally]

The rhetorical questions in anaphoric position (which use marked word order in Spanish) [micro-speech act: appeals: questions] invite the audience to agree with the Prime Minister's words and, thus, be seen as credible and convincing. And, yet, Rajoy mostly concentrates on informative micro-speech acts in his argumentation (having either marked or unmarked word order), since he had appeared in Parliament to explain the Bárcenas affair and the current economic and political situation in Spain (see Table 4). In (10) the Prime Minister further displays the argumentative strategy of resorting to the law to support his arguments, which is typical of various discourse 
genres, such as parliamentary debates (Van Dijk 2003, 71), while he argues against the illegality of Bárcenas's and the Socialist party's actions. This way, by appealing to the law, he strengthens the legal basis of his decisions: "The judge will determine what is appropriate about each one of the insinuations." With this sentence, Rajoy further uses the well-known strategy of leaving implicit meaning in the text, which consists in "presupposing information that is not shared or generally accepted and introducing it 'through the back door"' (our translation) (2003, 61). No doubt, with his words Rajoy implies that the claims over illegal payments from a slush fund run by the ex-treasurer are malicious insinuations; a claim that was not shared by many politicians in the audience, but one that could not be proven as false either.

Table 4. Raw numbers and percentages of micro-speech acts

\begin{tabular}{lcc}
\hline Feature & Percent & N \\
\hline $\begin{array}{lc}\text { MICRO-SPEECH ACTS-implementing- } \\
\text { and-sustaining-the-global-ones }\end{array}$ & $\mathbf{1 0 0 \%}$ & $\mathbf{1 4 6}$ \\
\hline Contact & $N=2(1.37 \%)$ & \\
Information & $N=81(55.48 \%)$ & \\
Appeals & $N=47(32.19 \%)$ & \\
Obligations & $N=16(10.96 \%)$ & \\
\hline
\end{tabular}

Rajoy displays various other argumentative strategies contributing to "Our" positive self-presentation, including:

1. He attempts to convince the audience that he is the victim of Bárcenas's and the opposing party's manipulative moves. For that purpose, he tries to demonstrate that his arguments are solid and, thus, he is a solid speaker (see Example 11).

(11) It is not up to me nor the Government, nor even the Chamber, but to judges to establish the truth about Mr. Bárcenas's malicious insinuations.

2. He attacks the opposing party for supporting the ex-treasurer to benefit their own political interests even at the expense of truth. For his attacks, he uses the opposition party's leader's own words as a powerful weapon - irony -, which does not leave anyone indifferent ${ }^{14}$ (see Example 12).

14. On the aftermath of the discourse numerous newspapers commented on Rajoy's strategy to attack the opposing leader's party Rubalcaba and its winning effect: [Rajoy has consistently punctuated his discourse with Alfredo Pérez Rubalcaba's literal quotations so as to transform them into an accusatory boomerang. Each expression was ended with the popular \#end-ofquote (official trending topic). The tone and the gesture accompanied Rajoy's hammer drill. [...] Rajoy's textual quotations have formed a winning lever. The attack has been frontal. Definitive broken bridges"] (own translation). (Gutiérrez-Rubí, A. El País, $2013<$ http://blogs.elpais.com/ micropolitica/2013/08/fin-de-la-cita.html>). 
(12) It has been rightly said and I quote: "judges in Spain are the ones who decide if accusations are true or not" (end of quote). Therefore, Your Honors, "I'll wait for justice to finish its work. It's what's reasonable and what should be done in all cases".

3. He uses fallacies to support his argumentation. For example, he uses an ad hominem fallacy (i.e. attacking the negative qualities of someone making a claim) to disregard the opposing party's accusations (see Example 13).

(13) Your Honors, it's impossible for me to satisfy those who proclaim beforehand that my explanations "do not coincide with the truth." It seems some people enjoy the benefit of already knowing the truth; thus, for that reason they are not required to say anything.

4. He uses frequent generalizations. For example, see Example 14.

(14) When one of my collaborators has undergone political or personal difficulties, I have shown him my support and solidarity. I have always acted like that.

In contrast, as part of Rajoy's general strategy of negative "Other-presentation", he also refers to the ex-treasurer, the opposing party and their leader in strongly negative terms ('their bad acts') and he does so often and implicitly (see Example 15).

(15) Honors, everyone knows that for Mr. Bárcenas it would have been impossible to create the scandal he tried to create, had he not had invaluable aids. There have been some who, individually or in group, have decided to take advantage of the situation for their own benefit. I am referring, among others, to those who applaud and cheer the deceit of papers and photocopies; those who transform every insinuation into vehement accusations, believing certain and proved all that is published and ignoring all that is refuted; those who see crimes with the same ease as they first saw green shoots; those who set themselves up judges to condemn without proof; those who allow themselves to be dragged along by an uncontrollable urgency and prefer not to wait until the truth is known, maybe because they are worried about the risk of not liking the truth or it not being in their interest, or because they do not have the political time to find out about it.

In (15), Rajoy accuses the "Others" (the Socialist party) of unfairly accusing him and his party without proof and he does so by giving specific negative details about "Their" actions in an attempt to convey a negative image about "Them". Certainly, the syntax of the sentences serves to ideologically mark the text, since the "Others" are the subject and topic of sentences: "those who applaud ...; those who transform ...." This way, "negative properties attributed to outgroups may be enhanced by focusing on their responsible agency" (Van Dijk 2011, 24). Agency and responsibility of the "Others" are further enhanced by using parallel syntactical structures, in which "los que" (those 
who) is repeated at the beginning of each sentence (anaphora). Such description associates the "Others" with unethical behavior and, thus, their credibility is reduced.

Further examination of the words used to describe "Us" and "Them" in Extract (15) reveals that they are fundamentally different: the "Others" are referred to indirectly on the majority of occasions ("those who see crimes", "those who set themselves up as judges"), since "the option [...] is not neutral" (our translation) (Van Dijk 2003, 60) in the knowledge that the audience will infer the missing meaning from their own discourse model or from the socio-cultural knowledge they have $(2003,60)$. However, the ex-treasurer is directly referred to as "Mr. Bárcenas," while Rajoy refers to "Us" - the PP Government - as "the Government" (see Example 10) and, thus, the words present no evaluative items, but are only used in terms of the role they play in the country. As in Martin Rojo and Van Dijk (1997, 543), we find that the forms selected contribute to the legitimation of discourse; that is, "through these forms, differences in authority and status are emphasized, and the authority of the institution is transferred to its representative and his discourse, while others are deprived of authority and social status." Also, in Example (15) the words and phrases are negative about "Them" (i.e. negatively evaluated) and the metaphors emphasize "Their" negative properties. Indeed, when referring to the opposing party, who are supporting the ex-treasurer to benefit their own interests, Rajoy employs several negative terms: "create the scandal," "take advantage of the situation for their own benefit," "transform every insinuation into vehement accusations" [appraisal: attitude: judgment: property: negative]. Similarly, the CONTAINER FOR CONTAINED metonymy ("papers and photocopies" 15 for "handwritten accounts") and THE ECONOMY IS A PLANT ("green shoots"), ${ }^{16}$ URGENCY IS AN UNCONTROLLABLE FORCE ("be dragged along by an uncontrollable urgency") and THE SOCIALISTS ARE AN AID FOR LAW BREAKERS metaphors ("invaluable aids") are negative about "Them". Therefore, the negative terms contribute to the idea that the "Others" are a threat to

15. PP politicians dismissed Bárcenas's secret ledgers as "photocopies of photocopies" (Collado, A. 2013. El PP desacredita los papeles de Bárcenas: "fotocopias de fotocopias" escritas de una sentada). [PP dismisses Bárcenas' papers: 'photocopies of photocopies' written in one sitting]. El Confidencial. <http://www.elconfidencial.com/espana/2013-02-04/el-pp-desacredita-los-papeles-de-barcenas-fotocopias-de-fotocopias-escritas-de-una-sentada_224723/>).

16. The Socialist Minister of Economy, Elena Salgado, was the first to use the expression "green shoots" in 2009 to talk about some incipient signs of recovery in the Spanish economy. The Socialist also made an electoral video, which showed a small plant growing on arid land ("El PSOE exhibe sus brotes verdes en su ultimo video electoral" [PSOE exhibits their green shoots in their latest electoral video] El País 2009). The expression was the butt of jokes, criticisms and humorous references on television, and also used by those opposing the Government, who employed it ironically to mock the Socialist economic policies: "It seems that the green shoots are of marihuana and Zapatero has smoked them" (Europa Press $2009<\mathrm{http}$ ://www.20minutos.es/ noticia/471953/0/bortes-verdes/marihuana/zapatero/>). 
"Us" - the PP Government and Spaniards. These results suggest that, also lexically and rhetorically, the speech contributes to the overall function of legitimation by using manipulative discourse.

There is little doubt that Members of Parliament understand perfectly Rajoy's moves of legitimization and manipulation, which would make them 'victims' of legitimate persuasion rather than powerless 'victims' of manipulation. And, yet, there are some contextual properties that can help us to distinguish between persuasion and manipulation. First, MPs lack crucial information that only belongs to the Government, which makes them susceptible to manipulation (e.g., despite the evidence, they cannot claim that the PP party had a double accounting system; they have no access to the documents that show the exact time period when Bárcenas was the PP party's treasurer; they cannot claim that PP party leaders had received payments on the side and, thus, they gave the donors political favors or contracts in exchange for the money). Second, PP MPs can hardly reject Rajoy's speech without putting the PP Government and the Prime Minister at risk. Third, no PP MP can acknowledge knowing about the existence of a slush fund in his party and hope to keep his job. Fourth, not supporting Rajoy's words may be explained for PP MPs as taking sides with the Socialist party. Obviously, non-PP MPs are not in such a tight position and, thus, can refuse to be manipulated (some did, since politicians from various political parties responded to Rajoy's speech and rejected his words). In sum, the PP MPs may have been manipulated into accepting Rajoy's words and into accepting the concrete act of some senior PP politicians' receiving illegal payments without them having political consequences.

\section{Conclusions}

The present study attempted to find out which manipulative processes Rajoy employed in his Parliamentary speech on 1st August 2013 so as to convince his audience that he and the Popular Party were innocent of receiving cash bonuses. The debate was selected because it came about within a context of a serious economic crisis in Spain and a political crisis in the Popular Party, which made it a good candidate for manipulation to legitimate the party's actions. For the analysis, we used Van Dijk's (2006) categorization of manipulation. Theoretically, manipulation is an illegitimate control of the manipulator over the manipulated so as to deceive them into believing that things are done to their best advantage, when they only benefit the manipulator. We also used Martin and White's (2005) Appraisal theory to study the language of evaluation and Lakoff and Johnson's (1980) conceptual metaphor theory to study metaphors. 
In this study, the analysis of manipulation has concluded that Rajoy's speech presents characteristics of ideological discourse, since it follows the general strategy of positive in-group presentation and negative out-group presentation, which has an overall legitimating function. "Our" good actions are described as correct and beneficial, at a specific and detailed level and are evaluated positively, whereas "Our" controversial actions are either ignored, described with few details or in euphemistic terms. "Their" bad actions are however described as deviant and threatening to "Us", with great detail and in hyperbolic terms. All this is accomplished with the aim of justifying Rajoy's words that he and his party are innocent of the ex-treasurer's accusations. At other levels of discourse, such denial of controversial actions are made manipulative, e.g., by lexical derogation of the "Others", syntactic and discourse order emphasis, concealment of agency and responsibility, thematically and rhetorically enhancing positive or negative actions and by adding positive or negative evaluations. However, the Prime Minister not only attempts to explain the negative properties of the "Others" based on a particularly unfavorable situation, but also he tries to offer the audience a general negative image of the "Others": the ex-treasurer is represented as breaking the law and a deviant, while the Socialist party are seen as being driven by self-interest and dishonesty. At the same time, Rajoy manages his own image and that of his party with a general positive strategy of self-presentation: he represents himself and his party as democrats who scrupulously respect the law, follow the principles of democracy, worry about Spaniards' economic stability and work hard to achieve it.

Manipulation of the audience may have been successful with some politicians since some requirements are met: the Prime Minister is in a dominant position over the audience, non-PP MPs lack crucial information that Rajoy is aware of, while PP MPs feel compelled by political circumstances. Also, Rajoy is seen to tell the truth, give solid arguments and describe actions that can be verified and, thus, his account of the events is seen as credible and those of the "Others" as non-credible. He further uses strategies to enhance the audience's feeling that the discourse is true: describing details, referring to reliable sources such as authoritative institutions (the High Court of Justice, the Public Prosecution) and the law, emphasizing his authority as the President of the Government and that of his party as the party in power by the electors' choice in the Presidential Elections, presenting himself as honest and reliable, providing proof and evidence for his words and using convincing arguments (although fallacious, on occasions). At the same time, Rajoy de-emphasizes the "Others" authority by associating them with self-interest, a violation of the law and, hence, with crime. These strategies of legitimization and de-legitimization are, therefore, linked to manipulation and "contribute to the management and the reproduction of power" (Martin Rojo and Van Dijk 1997, 562). Needless to say 
that, despite the requirements for manipulation, non-PP MPs understood Rajoy's manipulative moves and were able to reject his words; however, PP MPs felt politically obliged to accept the Prime Minister's words and could be, thus, helpless before manipulation.

Future studies could find out whether or not Rajoy's discourse served to manipulate the wider audience who watched the broadcasting emission of the speech and whether or not he actually achieved his purpose.

\section{References}

Allott, Nicholas. 2013. "Relevance Theory." In Perspectives on Linguistic Pragmatics, ed. by Alessandro Capone, Franco Lo Piparo, and Marco Carapezza, Vol. 2, 57-98. New York: Springer. doi:10.1007/978-3-319-01014-4_3

Blass, Regina. 2005. "Manipulation in the Speeches and Writings of Hitler and the NSDAP from a Relevance Theoretic Point of View." In Manipulation and Ideologies in the Twentieth Century: Discourse, Language, Mind, ed. by Louis de Saussure, and Peter Schulz, Vol. 17, 169-190. Amsterdam: John Benjamins. doi:10.1075/dapsac.17.09bla

Brinker, Klaus. 1997. Linguistische Textanalyse: Eine Einfuehrung in Grundbegriff und Methoden. Berlin: Erich Schmidt.

Cué, Carlos E., Miguel Jiménez, and Jose M. Moreno. 2013. "Rajoy Appears more often in Bárcenas' Ledgers than other PP Officials.” In El País. Available at: <http://elpais.com/elpais/2013/02/03/inenglish/1359913280_152138.html> (accessed April 3rd, 2015).

Dörnyei, Zoltán. 2007. Research Methods in Applied Linguistics. Oxford: Oxford University Press. Graham, Philip, Thomas Keenam, and Anne M. Dowd. 2004. "A Call to Arms at the End of History: A Discourse-Historical Analysis of George W. Bush's Declaration of War of Terror." Discourse and Society 15 (2-3): 199-221. doi:10.1177/0957926504041017

Kövecses, Zoltán. 2010. Metaphor: A Practical Introduction. Oxford: Oxford University Press.

Lakoff, George, and Mark Johnson. 1980. Metaphors We Live By. Chicago: University of Chicago Press.

Leech, Geoffrey. 1995. Principles of Pragmatics. London: Longman.

Leudar, Ivan, Victoria Marsland, and Jirí Nekvapil. 2004. "On Membership Categorization: 'Us', 'Them' and 'Doing Violence' in Political Discourse." Discourse and Society 15 (2-3): 243-266. doi: 10.1177/0957926504041019

Maillat, Didier, and Steve Oswald. 2007. "Defining Manipulative Discourse: The Pragmatics of Cognitive Illusions." International Review of Pragmatics 1: 348-370. doi: 10.1163/187730909X12535267111651

Martín Rojo, Luisa. 2000. "Enfrentamiento y consenso en los debates parlamentarios sobre política de inmigración en España [Confrontation and consensus in parliamentary debates about immigration policy in Spain]." Oralia 3: 113-148.

Martín Rojo, Luisa, and Teun A. van Dijk. 1997. "'There was a Problem, and it was Solved!': Legitimazing the Expulsion of 'Illegal' Migrants in Spanish Parliamentary Discourse." Discourse and Society 8 (4): 523-566. doi:10.1177/0957926597008004005

Martin, James, and Peter R. R. White. 2005. The Language of Evaluation: Appraisal in English. Basingstoke: Palgrave Macmillan. 
Oddo, John. 2011. "War Legitimation Discourse: Representing 'Us' and 'Them' in Four US Presidential Addresses." Discourse and Society 22 (3): 287-314. doi:10.1177/0957926510395442 Saussure, de Louis. 2005. "Manipulation and Cognitive Pragmatics: Preliminary Hypotheses." In Manipulation and Ideologies in the Twentieth Century: Discourse, Language and Mind, ed. by Louis Saussure and Peter Schultz, Vol. 17, 113-145. Amsterdam: John Benjamins. doi: 10.1075/dapsac.17.07sau

Saussure, de Louis, and Peter Schulz. 2005. "Introduction." In Manipulation and Ideologies in the Twentieth Century: Discourse, Language and Mind, ed. by Louis Saussure, and Peter Schulz, Vol. 17, 1-9. Amsterdam: John Benjamins. doi:10.1075/dapsac.17.02sau

Searle, John R. 1969. Speech Acts: An Essay in the Philosophy of Language. Cambridge: Cambridge University Press. doi:10.1017/CBO9781139173438

Şimon, Simona. 2008. “The Pragmatic Structure of Written Advertisements.” In Proceedings of the 5th International Conference on Professional Communication and Translation Studies: Politehnica University of Timişoara, ed. by R. Superceanu and Daniel Dejica, Vol. 1, 51-58. Timişoara: Politehnica Publishing House.

Sperber, Dan. 1994. "Understanding Verbal Understanding." In What is Intelligence? ed. by Jean Khalfa, 179-198. Cambridge: Cambridge University Press.

Sperber, Dan (ed.). 2000. “Introduction." In Metarepresentations: A Multidisciplinary Perspective, 3-16. New York: Oxford University Press.

Sperber, Dan, and Deirdre Wilson. 1995 [1986]. Relevance: Communication and Cognition. Oxford: Blackwell.

Van Dijk, Teun. 1992 [1977]. Text and Context: Explorations in the Semantics and Pragmatics of Discourse. London/New York: Longman.

Van Dijk, Teun. 1998. Ideology: A Multidisciplinary Approach. London: Sage.

Van Dijk, Teun. 2000. "News Racism: A Discourse Analytical Approach." In Ethnic Minorities and the Media, ed. by Simon Cottle, 33-49. Buckingham: Open University Press.

Van Dijk, Teun. 2001. "Multidisciplinary CDA: A Plea for Diversity." In Methods of Critical Discourse Analysis, ed. by Ruth Wodak, and Michael Meyer, 95-120. London: Sage. doi: $10.4135 / 9780857028020 . d 7$

Van Dijk, Teun. 2003. Ideología y discurso: Una introducción multidisciplinaria [Ideology and discourse: A multidisciplinary introduction]. 2a edición. Barcelona: Ariel Lingüística.

Van Dijk, Teun. 2005a. "Contextualization in Parliamentary Discourse: Aznar, Iraq and the Pragmatics of Lying." Congreso Discurso Oral, Almería 24th-26th November 2005. Available at: <http://www.discursos.org/> (accessed 17th February 2015).

Van Dijk, Teun. 2005b. "War Rhetoric of a Little Ally." Journal of Language and Politics 4 (1): 65-91. doi:10.1075/jlp.4.1.04dij

Van Dijk, Teun. 2006. “Discourse and Manipulation.” Discourse and Society 17 (2): 359-383. doi: 10.1177/0957926506060250

Van Dijk, Teun. 2012. “The Role of the Press in the Reproduction of Racism." In Migrations: Multidisciplinary Perspectives, ed. by Michi Messer, 15-29. Vienna: Springer. doi:10.1007/978-3-7091-0950-2_2

Van Eemeren, Frans. 2005. "Foreword: Preview by Review." In Manipulation and Ideologies in the Twentieth Century: Discourse, Language and Mind, ed. by Louis Saussure, and Peter Schulz, ix-xvi. Amsterdam: John Benjamins. doi:10.1075/dapsac.17.01eem

Wilson, Deirdre. 2000. “Metarepresentation in Linguistic Communication.” In Metarepresentations: A Multidisciplinary Perspective, ed. by Dan Sperber, 411-448. Oxford: Oxford University Press. 


\section{Author's address}

Ana Belén Cabrejas-Peñuelas

University of Valencia

Department of English and German Philology

Facultad de Filología, Traducción y Communicación

Blasco Ibañez 32, 46010 Valencia

Spain

ana.belen.cabrejas@uv.es 